\title{
Black American female Olympic Athletes have not reaped the same social standing and economic benefits that their counterparts have since the 1968 Olympics in Mexico City
}

\author{
Steven N. Waller, PhD ${ }^{1}$ Dawn M. Norwood, PhD² \\ LeQuez Spearman, $\mathrm{PhD}^{3} \bullet$ Fritz G. Polite, $\mathrm{PhD}^{4}$
}

\begin{abstract}
$\mathrm{T}$ This paper presents an abbreviated version of an 'elite' interview conducted with Madeline Manning-Mims. The 1968 Olympic protest was a pivotal moment in Olympic and American sports history. At the forefront of the protest was the pre-eminent sport sociologist Dr. Harry Edwards. Edwards' leadership catalyzed the African American boycott of the 1968 Olympics in Mexico City, however, Black female athletes were either silenced or recused themselves from the protest. A series of semi-structured, retrospective interview questions were posed to Manning-Mims to gather her perspectives on the progress that Black American, women Olympic athletes have made in the USA from 1968 to present. Analysis of the 'expert' interview with Mims indicated that: 1) the social conditions in the United States that have plagued Black female athletes in 1968 had changed for the better; 2) on the whole Black U.S. athletes in the second millennium have become "commoditized" after the Olympics and gain substantially from their celebrity; and 3) Black female athletes can become enslaved to the economics of their celebrity if they are not careful.
\end{abstract}

Keywords: 1968 Olympics, Black Female Athletes, Madeline Manning Mims

\footnotetext{
${ }^{1}$ Department of Kinesiology, Recreation, and Sport Studies, The University of Tennessee-

${ }^{2}$ School of Sport Sciences, Wingate University

${ }^{3}$ Department of Counseling, Kinesiology \& Special Education, Midwestern State University

${ }^{4}$ Sport Management Program, College of Business, Shenandoah University
} 
Black American female Olympic Athletes have not reaped the same social standing and economic benefits that their counterparts have since the 1968 Olympics in Mexico City

As the 2016 Olympics approaches the sporting horizon, it is important to reflect upon the progress that Black Americans and importantly Black American women have made in the modern Olympic movement. At the London Games in 1948, Olympic high jumper Alice Coachman established the standard for African American women in the Olympics by capturing the gold medal when she cleared 5-61/4 (1.68), setting a new Games record (sports-reference.com, n.d.). Twelve years later, track and field luminary Wilma Rudolph, would win three gold medals at Rome in 1960 to help solidify the position of African American women as sterling performers. Despite the undeniable success of numerous Black athletes in the Olympic Games throughout the twentieth century, their status on and off the field has often times been paradoxical. A significant number of Black athletes have felt they had to negotiate the often complex issues of using their elite athlete status to represent a country in which they were underserved and discriminated against due to their minority status. The participation of Black athletes in the Olympic Games has often revealed and mirrored inequalities in society as a whole. For instance, before (and during) the Civil Rights Movement, African American athletes were members of the USA Olympic team, and revered within this role, yet when they returned to the USA they were unable to share public spaces with White people or even drink from the same water fountains.

In the fall of 1967, Black athletes formed the Olympic Project for Human Rights (OPHR) to organize an African American boycott of the 1968 Olympics in Mexico City. Harry Edwards, 200-meter star Tommie Smith and 400-meter sprinter Lee Evans, played a catalytic role in the organizing efforts through the start of the Games. The three organizers hoped that their efforts would cast a bright light on the social and economic injustices Black Americans were facing in the United States. Edwards' group, the OPHR, gained support from several world-class athletes and civil rights leaders but the full manifestation of the boycott never materialized.

Perhaps the most acclaimed milestone of the 1968 Mexico City Games are the photographs of Smith and Carlos standing on the medal podium with heads bowed and fists raised. Smith and Carlos were stirred by the suggestion of Edwards, who asked them and all the other Black male athletes to join together and boycott the games. Still moved by Edwards' words, Smith and Carlos secretly planned a non-violent protest. In the 200-meter race, Smith won the gold medal and Carlos the bronze. As the American flag rose and the Star-Spangled Banner played, the two closed their eyes, bowed their heads, and began their protest.

While the protest seems relatively tame by today's standards, the actions of Smith and Carlos were met with such disdain that they were suspended from 
the national team and banned from the Olympic Village. Many people thought that political statements had no place in the supposedly apolitical Olympic Games. Those that opposed the protest cried out that the actions were militant and disgraced Americans. Supporters, on the other hand, were moved by the duo's actions and praised them for their bravery. The four Black women runners on the U.S. 400-meter relay team dedicated their victory to the exiled sprinters (Smithsonian, 2008).

Withstanding the influences of the OPHR, the organized protest, and the actions of Smith and Carlos in 1968, several questions surfaced about the progress that has been made for Black Olympic athletes, especially Black women that represented the United States. One of the interesting points related to the 1968 protest was that Black women were not invited to participate in the protest or the work of OPHR (Hartman, 2003). In an interview with ColorLines, OPHR organizer Dr. Harry Edwards noted the following while commenting on the failures of OPHR made the following statement:

We also didn't do the job we should have done in terms of women. Even with all of those Black women athletes in the Olympics, we never really approached them. In today's language that means we were sexist, an indictment that could be extended to the whole civil rights movement (Leonard, 1998).

Bass (2002) also offers that despite the importance of African American women to the U.S. track and field effort at the 1968 Olympics sterling athletes such as Wyomia Tyus, Barbara Ferrell, Madeline Manning, Doris Brown, Margaret Bailes, Jarvis Scott, and Mildrette Netter were systematically excluded from the roles of the OPHR (p. 189).

The purpose of this study is to provide a retrospective reflection on the state of Black Americans, female Olympic athletes from the "expert" perspective of Madeline Manning Mims. The purpose of the interview is to determine whether the social and economic conditions have shifted for Black Olympians since the Mexico City Olympics in 1968. Toward the end of consistency and conciseness in the development of this research note the term "Black Olympian" is used as a substitute for the phrase "Black American, female, Olympic athlete."

\section{Profile of Madeline Manning Mims}

Madeline Manning Mims is an alumnus of Tennessee State University (TSU) and a famed member of the acclaimed 'TigerBelles' coached by the legendary Edward S. Temple. 
Black American female Olympic Athletes have not reaped the same social standing and economic benefits that their counterparts have since the 1968 Olympics in Mexico City

During her athletic career at TSU, she was named as an AAU AllAmerican in 1968, 1969, 1970, 1971, and 1972 (Salisbury, 2009). Between 1967 and 1981 she amassed 10 national titles and set a number of American records. Mims was a standout participant track and field participant in the 1968, 1972, and 1976 Summer Olympics. At the 1968 Olympics, Mims became the first American woman to win a gold medal in the 800-meters. At the 1972 Games in Munich she won a silver medal in the 4 x 400 meter relay with teammates Mable Fergerson, Kathy Hammond, and Cheryl Toussaint. In 1984 she was inducted into the United States National Track and Field Hall of Fame.

Dr. Mims is founder and president of the United States Council for Sports Chaplaincy and has served as a sport chaplain at the 1988 Seoul, 1992 Barcelona, 1996 Atlanta, 2000 Sydney, 2004 Athens, and 2008 Beijing Olympic Games. She is an ordained clergyperson/ evangelist and recently completed studying for a Doctor of Ministry (D.Min.) degree specializing in sport chaplaincy at Oral Roberts University in Tulsa, Oklahoma, and is one of the team chaplains of the Tulsa Shock of the WNBA.

\section{Methods}

To capture the complex social phenomenon such as the fluctuating state of Black Olympic athletes it is essential to occupy the 'elite' athletes in a given sport area. Elites are "people who occupy, by heritage, merit or circumstance, a key place in power networks" (Undheim, 2006, p. 14). The 'elite,' possess insight knowledge through their participative experience and expertise that provides unique insights into key events in history (Richards, 1996). Expert interviews tend to be more open ended than the focused interview so that the interviewee can stress his or her definition of, structure, and relevant data related to a situation (Odendahl \& Shaw, 2002). Scholars such as Coleman (1996), Hertz and Imber (1995), Kezar (2002) and Ostrander (1995) argued that "elite" studies have been neglected in the qualitative research method literature.

In light of the historical and comparative value of the subject matter, a semistructured interview was conducted utilizing an 11 question interview schedule. The questions were grounded in the cumulative experiences of Mims as an "elite" Olympian. The focal point was Mims' reflections and experiences with the Olympic movement in the United States. The interview was conducted using an "audio-bridge" in a high-tech conference room located in the communications department on a land-grant university in the southeast. The subject was dialed in to a dedicated line to take part in the interview and was told that she would have an opportunity to "member check" her comments in the transcript within ten days of the completion of the interview. Upon completion of the interview, the deliberations were audibly verified for quality and content and then transcribed. 
Upon receipt of the transcript it was reviewed and sent back to the subject for verification as a means of member checking (Andrew, Pedersen, \& McEvoy, 2011; Gratton \& Jones, 2010).

To further guard against threats to the reliability and validity of the interview, the researchers "vetted" the subject - conducted a diligent review of the background of the "expert" to validate some of the key claims made. As a part of the vetting process the researchers: 1) examined archived materials on the subject at the Tennessee State University; 2) consulted with Olympic track and field athletes of the same era; 3) examined her participation in the Olympic movement from 1968 to present as revealed in the popular press and other sources related sources; and 4) and avoided the use of impact questions in the interview schedule (Aberdach \& Rockman, 2002; Berry, 2002; Kezar, 2003). The aforementioned methods were also used for the purpose of triangulation. Table 1 provides a brief summary of the primary sources used to "vett" the subject.

The interview is presented below is formatted using the acronym "IN" as a surrogate for the interviewer and "MM" to denote the responses of Madeline Manning Mims.

\section{The Interview with Madeline Manning-Mims}

IN: What social conditions were prevalent in the United States in 1968 that "triggered" the protest at the Mexico City games?

MM: There was civil unrest between the Blacks and Whites in America during that time. Fighting and distrust among citizens over racial issues raged out of control, and poured into the streets of our nation. There was tension placed on Black Olympians to boycott the 1968 Olympic Games in protest of racial injustices that were taking place in America. This pressure triggered individual responses that were independent of the team. At the same time, it developed respect for one another's personal passion in response to our nation's problems. It also drew us close to one another as we dealt with a common problem at home, while the world watched via television.

As a matter of fact, things have changed in many positive ways since then, but even in 2012 we are experiencing some of the same conditions. There are still these social and economic "gaps" for a lot of Black athletes. For example, back then, no "amateur" athlete was allowed to make money creating very difficult financial circumstances when one returned home. There was some money made overseas for the men, but the women did not have the same platform to work from in Europe. This made for short careers in sports due to the lack of finances. 
Black American female Olympic Athletes have not reaped the same social standing and economic benefits that their counterparts have since the 1968 Olympics in Mexico City

IN: During the same period, how were Black athletes treated in the Olympic Movement here in the United States?

MM. Black athletes were treated with the same strict rules for competition that other racial groups encountered by our sports governing bodies. The USOC was the governing body over all U.S. Olympic sports and worked with their governing bodies. I can't say we were treated any different. It was hard for us all. Many of the athletes followed the work of Harry Edwards and several others involved with the Olympic Project for Human Rights. I think what they did helped to shine a light on some of the social problems we were having here at home.

IN: Reflecting back to 1968, what role did Black women play in the 1968 Olympic protests?

MM: We did not really have a role. It was made clear to all teammates that any expression of protest would be an individual decision. Realistically, Black women were not openly invited to participate in the protest, but we were informed about the possibilities of there being a boycott. The reason we were not asked leans more to the protection of our character being attacked by media or people who may have perceived us as non-American. I believe the way Black female athletes did their part was by being at their best when the competition began.

In my sport, track and field, there were plenty of Black female athletes competing at the 1968 Games, and our runners were the best in the U.S. and the world. Black females competed in the jumping field events, but were not strong enough in the throwing events to make the team. I was pioneering the path for women of color worldwide in the 800 meters at that time. This was the longest running event women could compete in at the 68 Games. The myth was that women of color could not run long distances well, if at all. I shattered that myth by winning 40 meters over my European competitors, setting a new world and Olympic record. We were not there to protest. We had enough to fight against to prove we belonged among the world's greatest athletes. We did our part by dismantling the myths.

What is important also is that Black athletes, especially women, have to see themselves as "change agents." All of us, men and women [Black] can promote social change at every Olympic Games by performing well, displaying integrity, and fair play. Your actions speak louder than words. After people see what you are portraying on the playing field, then they will determine if they should listen to what you have to say. 
IN: Were you active at all with OPHR and do you think the organization is needed today?

MM. No. For the most part, I was quite ignorant of the details given me, which were few. Part of this stemmed from me being one of the youngest on the T\&F [track and field] team, and well protected. My teammates knew my potential to win a gold medal, and did not want me distracted. The other factor is that Black women were not openly recruited to take part in OPHR. Many of the organizers simply did not want to see the women surrounded by controversy because of the possible implications.

The ideals that originated the OPHR were set up for a specific time and circumstance in America. They do not totally fit the current differences we may have now. Nevertheless, Human Rights for all peoples at all times and places should be of utmost importance to humanity at large.

IN: Dr. Mims, back in 1968, some prominent Black athletes felt that sport was an equalizer for Blacks, and protests would not prompt racial harmony. What is your position on this today?

MM. Sport for Black athletes in the 60's did give some sense of leveling for Blacks through the media. Protesting for racial harmony was frowned upon and thought of as un-American. Tommy Smith, the gold medalist in the men's 200 meter run, shared with the 1968 Olympic Track and Field team that we really had nothing to say until we won, because who would listen to us? I agree. You win, and they will come to you to hear what you have to say. You lose, and they will speak for you.

IN: What about the case of Black female athletes? How did racism and sexism collide to create potentially oppressing conditions for Black women?

MM: Black female athletes in the U.S. were not under a lot of pressure to boycott in protest of racism or sexism, but moreover to prove their worth as world-class athletes who would be recognized for their ability to compete at that level. We never received the attention that the men received; therefore we were silently in the background when it came to our voice on these issues. I believe that our Black male teammates were somewhat protective of any verbal or media attacks on us as well.

IN: Madeline, on the whole, do you believe things have gotten better for Black women Olympic athletes since 1968?

MM: For the first time in Olympic history, elite Olympians are able to make a good living financially while doing the very thing they were born to do best, compete. They see their vocation as part of the entertainment world and treat it as such. A lot more is involved now than just the activity of competing 
Black American female Olympic Athletes have not reaped the same social standing and economic benefits that their counterparts have since the 1968 Olympics in Mexico City

well. This may include coaching, agent/manager, sports doctor, chiropractor, sports trainer, massage therapist, nutritionist, sports psychologist, sports chaplain, sponsor, and any other entity that may enhance the life of the athlete in their vocation. The one thing lacking is a sense of loyalty to the sport for the love of the sport. It has become more of a love of money, than of sport, although I don't doubt that there has to be a love of the sport included somewhere for one to put their bodies through the rigorous training elite athletes must maintain to get to and stay on top. The motivation is MONEY!

IN: Madeline, do you think that the "standing" of Black female Olympians has improved over time?

MM: Currently, yes, there are more opportunities for Black female athletes to gain status and use their celebrity to do good, but still, women are not on the same financial scale that the men are. The elite athletes do well for themselves compared to our $\$ 12$ a day per diem in 68 . Because of the financial increase over the years, Black females are staying in the sport longer, marketing their talents to increase their finances and hopefully, learning to invest wisely for their future.

IN: Madeline, in your assessment, have Black female Olympians experienced significant economic gains from the "free enterprise" aspect of the Olympics, namely sponsorships and endorsement deals after the Olympics?

MM: Business or free enterprise is part of the nature of entertainment. It can bless if used wisely, and curse if abused. It affects all races the same. During the time of increase, it would be wise to have a good manager or mentor to help young athletes make wise choices financially.

Post-Olympic economic gains for the Black female Olympian have grown with media exposure. If she has the talent, she could go into television broadcasting, travel on the speaking circuit, write and give back to her sport, make personal appearances as a celebrity guest, etc. There are more opportunities today offered than years ago. For example, Black women in sports improved their professional standing and marketability by their performances at the 2012 London Olympic Games. When you look at the outstanding performances of Black women like Sanya Richards-Ross, Carmelita Jeter, and Allyson Felix in track and field; Gabrielle Douglas in gymnastics; and even Serena Williams in tennis, they should translate into healthy sponsorship deals. By far, the economic gains experienced by women in 2012 far exceed those of Black women who competed in previous Olympics. If everything holds constant, they should be even better for women and Black women after the 2016 Olympics in Rio. 
IN: Some cultural critics suggest that athletes are $\$ 40$ million dollar slaves. Do you consider this to be true with respect to Black women that are Olympians?

MM: I wish I was one! Anytime you serve the public with your gift, you become a servant/slave to all. That is not a position of shame when viewing it from a positive perspective of giving back what you have been so blessed with as an athlete. Gifts are God-given to prosper and be a bearer of good success. There is nothing shameful about Black women that are high caliber Olympic athletes taking full advantage of their stardom via commercials, product sells, television appearances, speaking engagements, and performances on the sports circuits. The African American women that excelled at the London Games [2012] are only reaping the fruits of their sacrifice and hard work. I think an Olympic athlete's good moral standards convey an open book to his or her personal and economic priorities. When one is anchored in strong morals, values, and faith it greatly reduces the problem of being trapped by money and fame.

Truthfully, Black female Olympians are no more enslaved than any other athlete. They can use their opportunities to 'cash in' on benefits offered just as any other male or female athlete. It is up to them on how to choose wisely the prospects and people who offer these opportunities. For example, Marion Jones has said her biggest mistake was trusting and being around people who were not thinking of her welfare, but of their own greed. She has matured from the consequences and moved on with her life nicely.

IN: Finally, having been an Olympic track and field standout, and most recently, a chaplain in the Olympic Village, you have had an opportunity to see Black American women at both their peak performances and when they experienced heartbreaking losses. Withstanding your history as an Olympian, what do you think the future might hold for Black American women?

MM: I would agree that Black women in sports improved their professional standings by their performances at the 2012 London Olympic Games. The American Olympic women performing at the London Games were outstanding, outshining the men's performances. So many of these elite Black Olympic females will help grow their sport, giving hope to many other little Black girls to compete in the future. As we move into the 2016 Games I'm going to remain confident that things will continue to improve for all women who are Olympic athletes.

\section{Discussion}

The primary purpose of this elite interview was to examine the progress that Black Olympians, inclusive of Black females, have made since the 1968 Mexico City boycott, through an "expert" perspective. Of particular interest 
Black American female Olympic Athletes have not reaped the same social standing and economic benefits that their counterparts have since the 1968 Olympics in Mexico City

to this research endeavor were the insights about Black female Olympians and their struggles since 1968. Finally, we sought to probe about the benefits that potentially accrue, post-Olympics to Black athletes and the economic "spillover" from the Olympics.

\section{Black Women in the Olympics}

The position of Black women in America has often been one of constant struggle to find her voice and for it to be heard. This can be attributed to what Kimbele' Crenshaw (1995) refers to as the intersectionality of race and gender. Black women's issues of race are enveloped with the races issues of Black males, while their issues surrounding gender are either masked under the umbrella of issues pontificated by White women and/or subsequently ignored by White women. With the work and activism of scholars such as bell hooks and Patricia Hill Collins, a socio-cultural voice for Black women has been carved out but, their struggle in American society is ongoing. And the world of sport has not been exempt from this struggle. Even with the overall progress of Blacks in the Olympics, Black females have historically been and, to some extent, continue to be displaced as they deal with the never-ending battle of transforming the oppressive views of women and girls in sport.

\section{Black Women in Sport}

It is no secret that America has historically held and perpetuated a marginalized ideology of women. In the early 1920s, this ideology permeated sport. As a culmination to the Women's Suffrage Movement, the Nineteenth Amendment was passed in 1920 ratifying the right for women to vote in America, though Black women, and Black men, would illegally be denied this right for decades thereafter. In a parallel historical event in 1920, women made their first official appearance as athletes of the U.S. Olympic Team that competed at Antwerp (Dyerson, 2003). In sports, women were not received well by their male counterparts thus, continuing the arduous task of gaining gender equality in both arenas. There were very few events offered for women to compete in at the Olympic Games. Only the elite sport of tennis was seen as somewhat acceptable for female athletes. This was in large part due to the face that tennis upheld many of the traditional ideals of womanhood - to be prim, proper, and feminine. Tennis was much more inclusive than other sports such as track and field but, was not inclusive of race (Lansbury, 2001). Probably more than anything, it was, and still is, an exclusive sport using economic class to separate the "haves" from the "have nots." 
Though the entry of women into the 1920 Olympic Games was progress on some level, the progress was slow to include Black women. The U.S. Olympics did not see its first African American females on a team until 1933, thirteen years after women first competed in the Games. Louis Stokes and Tydia Pickett made the U.S. track and field team but did not actually compete in the Games because their White coach would not allow them to because they were Black (Davis, 1992). Again, the Black female athlete found herself displaced in the Olympics, which would continue even through the infamous Olympic Project for Human Rights in 1968.

In an interview with OPHR organizer Harry Edwards (2011) stated, “Over the years while women's participation in sports and in the Olympics increased, the respect for women as athletes did not increase." Black female athletes probably found themselves more susceptible to unfair scrutiny and lack of respect. Further elucidating on Black women's participation in sport Edwards commented, [Female] athletes who were tremendously gifted and performed well often times had their femininity questioned. If they were White, they were likely to be seen as something less than fully feminine. If they were Black, they were likely to be seen and compared to animals in the sense that Black males were often seen to be more instinctual, animalistic, and so forth (Edwards, personal interview, 2011).

The proverbial double-edged sword of being Black and female manifested itself through their ultimate exclusion from the Olympic Project for Human Rights in '68. This was in large part due to the prevailing, perhaps a little misguided, idea that, ...once we dealt with race we had dealt with all of the problems that Blacks confronted in American society, not realizing in the mainstream movement, that a lot of what happens to Black women doesn't happen to them because they are Black, it happens to them because they are women (Edwards, personal interview, 2011).

Depending on who is asked, particularly Black women, this conclusion is debatable. Nevertheless, it was the prevailing thought on Black women in the '68 Olympic Project. Moreover, it was thought that because of the unanchored and unpopular state of women athletes in the Olympics and sport at large, the participation of Black female athletes in the Project would be more to their detriment. Furthermore Edwards concluded, when we organized the Olympic Project for Human Rights in the 1960s, I realized that to ask [Black] women to make that sacrifice in terms of speaking out and speaking up about issues of race would have had little or no impact relative to the status of women in sports (Edwards, personal interview, 2011). 
Black American female Olympic Athletes have not reaped the same social standing and economic benefits that their counterparts have since the 1968 Olympics in Mexico City

Black women enjoyed some success at the Mexico City Games and judging from the Olympic and the White American response to John Smith and Tommie Carlos' symbol of protest, their exclusion, or some would say 'shielding,' from the Project may have been a blessing in disguise. The passage of Title IX followed the Mexico City Games soon after in 1972 and opened the flood gates to girls' and women's participation in sport. Even with the giant leap in participation numbers and more doors being opened to female athletes, Black female athletes have still found themselves at the crossroads of discrimination based on sex and race in sport.

\section{Still Vying for Position}

On the surface of sport in the present day, the list of notable Black female athletes is easier to name than, say, just 20 or 30 years ago. There are, of course, Venus and Serena Williams in tennis, Candace Parker and Lisa Leslie in basketball, Gail Devers and Allison Felix in track and field, and even Laila Ali in boxing. Despite the apparent success and growth of Black females in sport post Title IX, they are still discriminated against. According to Donna Lopiano of the Women's Sport Foundation, “African American females represent less than five percent of high school athletes, less than 10 percent of college athletes, less than two percent of all coaches, and less than one percent of all athletic administrators" (Woods, 2007, p. 195). With Black females underrepresented at the high school and collegiate amateur levels, in all likelihood they will continue to be underrepresented at the Olympic Games, with the exception of sports where Black female athletes are generally relegated, such as basketball and track and field, due to them being less exclusive than sports like gymnastics.

\section{Verisimilitude of the Interview}

For as much as the "expert' interview is a useful tool in the qualitative research methods arsenal, one of its inherent problems lies in the amplification of information presented by the informant. Verisimilitude refers to the trustworthiness, authenticity, credibility of information presented to another (dictionary.com, n.d.). In essence, the term implies believability. In light of the vetting of the subject and the triangulation of information sources, we had a strong basis for testing the narrative offered by our subject. Consistently, her responses aligned with the socio-political-cultural climate of the era in which she participated in track and field as an Olympic caliber athlete. The historicity of the events she addressed during her interview were consistent with those of sport sociologists that critique the Olympic participation of U.S. athletes from 1968 to present (Bass, 2002; Billings, 2008; Hartman, 2003). Moreover, her unscripted responses to our queries flowed effortlessly and served as a testament 
to the impact that her Olympic experiences as a Black, female, American athlete had on her life. Overall, the research team found the content of Madeline Manning Mim's interview to be trustworthy, genuine and accurate.

\section{Limitations}

One of the limitations to the study is the trustworthiness of the information given by the subject. While in this interview there were no overt efforts to intentionally mislead the interviewer, the psychological and emotional attachment to the subject matter may have impacted some of her responses. Secondly, while the elite interview is a very viable research method its singular nature reveals one its flaws- the reliance on the information transmitted by the informant. Conducting interviews with at least two or more subjects who were African American, female and an Olympic caliber track and field athletes of the same era that have attained expert status would remedy this challenge. Finally, the elite interview is exceptionally valuable for the purposes of framing a topic but it does not replace the need for more rigorous qualitative research methods.

\section{Conclusion}

Throughout the interview and paper, we have explored the social standing of Black female Olympians, both past and present. The interview with Madeline Manning Mims has provided invaluable retrospective insights about the 1968 Olympic protests, as well as the role of Black female Olympians in the protest. It is without question that Black female athletes have made significant inroads, relative to their past conditions at various Olympiads in the last century. Black female Olympians, including Jackie Joyner-Kersee and the late Florence GriffithJoyner (Flo Jo) became household names, paving the way for more Black female Olympians in the modern era. Vonetta Flowers, in becoming the first African American ever to win an Olympic Gold medal at the Winter Olympics, was tapped to carry the American flag at the closing ceremonies, have her picture grace the front pages of several dailies, and appear on the Today Show with Katie Couric.

Despite contemporary society's promise of progression towards egalitarianism and fairness, in all facets of society, including sport, there are still residual holdovers from the past that still plague all women, irrespective of their race or class. Mims noted that, with respect to money and sponsorships, women still lag behind their male counterparts in sport, and this inequality has much to do with the media's irreverence for women sport. Billings (2008), an authority on the Olympics, noted that the voluminous coverage of women's 
Black American female Olympic Athletes have not reaped the same social standing and economic benefits that their counterparts have since the 1968 Olympics in Mexico City

sports still pales in comparison to that of men. Coupled with their status as women, Black women must negotiate within the constraints of them being persons of color and female, as the literature suggests that the intersection of race and gender is more of a hardship for them. In short, Black women have found that the "double whammy" of race and gender yields grave limitations for their employment prospects in and out of sport.

As Mims suggested, the commodification and exploitation of Black female athletes in sport is "neither no less nor more" than that of Whites, but the former gold medalist advises Olympians to take special care of their Godgiven talent. While it remains to be seen whether Black female athletes will become the metaphorical " $\$ 40$ million dollar slave" (Rhoden, 2006), a tag that has been attached to Black male athletes, several of them have witnessed firsthand the exploitative conventions of the free-enterprise Olympics. Cole and Mobley (2005) noted that in instances of allegations of performance enhancing drugs, the bodies Black of athletes, especially females, are subjected to even a greater modicum of surveillance. Moreover, Cole and Mobley further stated that the scrutiny given high performing world class athletes "is symptomatic of America's preoccupation and fascination with African American bodies, the cultural anxieties surrounding those bodies, and the use of Black bodies in interpreting U.S. drug scandals in general and the U.S. sport-drug scandal more specifically" (p. 6). To this end, the name of Griffith-Joyner resonates as this stellar athlete who had to combat allegations of steroid use. While it is incumbent upon Black female athletes to follow the call of Mims and closely comb through the personalities within their inner circle, individuals themselves are still penalized by the free-enterprise aspects of market-oriented sport, in which they are simply cogs in the machine. With the 2012 Summer Olympics in London behind us, it is important for all to reflect and comment on the social standing of athletes from all races, and this elite interview with Rev. Mims provided us with a unique and much needed perspective on the condition of Black female athletes, both past and present.

Perhaps the ultimate showing of Black female athletes coming full circle at an Olympic Games will be when one is heralded as the "sweetheart" of the Olympics for the United States. Though the U.S. has indeed seen some great Black female Olympians throughout the years, mainstream America has never latched on to one as they have done with White female Olympians in the past such as gymnasts Mary Lou Retton and Shannon Miller, or figure skaters Dorothy Hamill and Peggy Fleming, who have all been dubbed "America's sweetheart" during their Olympic appearances and success. All these women share commonalities that made them "right" for the title. They are White right color; and they competed in the right sports - those deemed "feminine." 
This is not to say that Black female athletes have not enjoyed periods of feeling the support of Americans during their moments of glory in the Olympic Games however, it has not been to the same, long-lasting extent as their White counterparts. What the future holds for Black female athletes in the Olympics will depend heavily on a radical shift in society's view on women in sport and a radical shift in race relations in America. Expert interviews such as this one with track and field Olympian Madeline Manning Mims helps us to understand the historical trappings of what it meant to be a Black Olympian in an era of turmoil and unrest, but it also helps us to understand the present and frame the future for Black women as Olympians.

\section{References}

(n.d.). Verisimilitude. Retrieved from http://www.dictionary.com/browse/verisimilitude.

Aberbach, J. D., \& Rockman, B. A. (2002). Conducting and coding elite interviews. PS: Political Science \& Politics, 35(04), 673-676.

Andrew, D.P.S., Pedersen, P.M., \& McEvoy, C.D. (2011). Research methods and design in sport management. Champaign, IL: Human Kinetics.

Bass, A. (2002). Not the triumph but the struggle: The 1968 Olympics and the making of the Black athlete. Minneapolis: University of Minnesota Press.

Berry, J. M. (2002). Validity and reliability issues in elite interviewing. PS: Political Science \& Politics, 35(04), 679-682.

Billings, A. (2008). Competing on the same stage: Gender and the Olympic telecasts. Olympic media: Inside the biggest show on television (pp.124-137). New York: Routledge.

Cole, C.L. \& Mobley, A. (2005). American steroids: Using race and gender. Journal of Sport and Social Issues, 29, (3), 3-8.

Coleman, S. (1996). Obstacles and opportunities in access to professional work organizations for long-term fieldwork: the case study of Japanese laboratories. Human Organization, 55(3), 334-343.

Crenshaw, K. (1995). Mapping the margins: Intersectionality, identity politics, and violence against women of color. In Crenshaw, K., Gotanda, N., Peller, G., \& Thomas, K. (Eds.), Critical race theory: The key writings that formed the movement (pp. 357-383). New York: The New Press. 
Black American female Olympic Athletes have not reaped the same social standing and economic benefits that their counterparts have since the 1968 Olympics in Mexico City

Davis, M. (1992). Black American women in Olympic track and field: A Complete illustrated reference. Jefferson, NC: McFarland \& Company, Incorporated Publishers.

Dyerson, M. (2003). Icons of liberty or objects of desire? American women Olympians and the politics of consumption, Journal of Contemporary History, 38(3), 435-460.

Gratton, C. \& Jones, I. (2010). Research methods for sport studies. New York: Routledge.

Hartman, D. (2003). Race, culture, and the revolt of the Black athlete: The 1968 Olympic protests and their aftermath. Chicago: The University of Chicago Press.

Hertz, R., \& Imber, J.B. (1995). Studying elites using qualitative methods. London: Sage.

Kezar, A. (2003). Transformational elite interviews: Principles and problems. Qualitative Inquiry, 9(3), 395.

Lansbury, J. (2001). "The Tuskegee flash" and "the slender Harlem stroker": Black women athletes on the margin, Journal of Sport History, 28(2), 233-252.

Leonard, D. (1998). What happened to the revolt of the Black athlete? Retrieved from http://colorlines.com/archives/1998/06/what_happened_to_the_ revolt_of_the_Black_athl ete.html.

Manning Mims, M. (2000). The hope of glory. Anaheim, CA: KNI, Inc.

ClevelandWomen.com (nd). Madeline Manning Mims Ran for Gold and Works for Salvation. Retrieved from http://www.clevelandwomen.com/people/ madeline-manning-mims.htm.

Odendahl, T., \& Shaw, A. (2002). Interviewing elites. In J. Gubrium \& J. Holstein (Eds.), Handbook of interview research: Context and methodology (pp. 299-316). Thousand Oaks, CA: Sage.

Ostrander, S. (1995). Surely you're not in this just to be helpful: Access, rapport, and interviews on three studies of elites. In R. Hertz \& J. Imber (Eds.), Studying elites using qualitative methods (pp. 133-150). Thousand Oaks, CA: Sage.

Richards, D. (1996). Elite interviewing: Approaches and pitfalls. Politics, 16(3), 199-204. doi: 10.1111/j.1467-9256.1996.tb00039.x. 
Rhoden, W. (2006). Forty million dollar slaves: The rise, fall, and redemption of the Black athlete. New York: Crown.

Salisbury, T.M. (2009). First to the finish line: The Tennessee State Tigerbelles 1

944-1994 (Unpublished doctoral dissertation). The University of North Carolina Greensboro.

Smith, T. (2005). "Why Negroes Should Boycott," Sport, March 1968, quoted in D. Wiggins and P. Miller (Eds.), The Unlevel Playing Field: A Documentary History of the African American Experience in Sport, p. 290. Champaign, IL: University of Illinois Press.

Smithsonian.com (2008). Olympic athletes who took a stand. Retrieved from http://www.smithsonianmag.com/people-places/indelibleolympics-200808.html.

Sports-reference.com (n.d.). Alice Coachman-Biography. Retrieved from http://www.sports-reference.com/olympics/athletes/co/alice-coachman-1. html.

Undheim, T.A. (2006). How sociologists can access the high tech elite. In S.N. Hesse-Biber \& P. Leavy (Eds.), Emergent methods in social research, (pp. 1342). Thousand Oaks, CA: Sage.

Woods, R. (2007). Social issues in sport. Champaign, IL: Human Kinetics.

Zirin, D. (2005), What's my name fool? Chicago: Haymarket Books. 
Black American female Olympic Athletes have not reaped the same social standing and economic benefits that their counterparts have since the 1968 Olympics in Mexico City

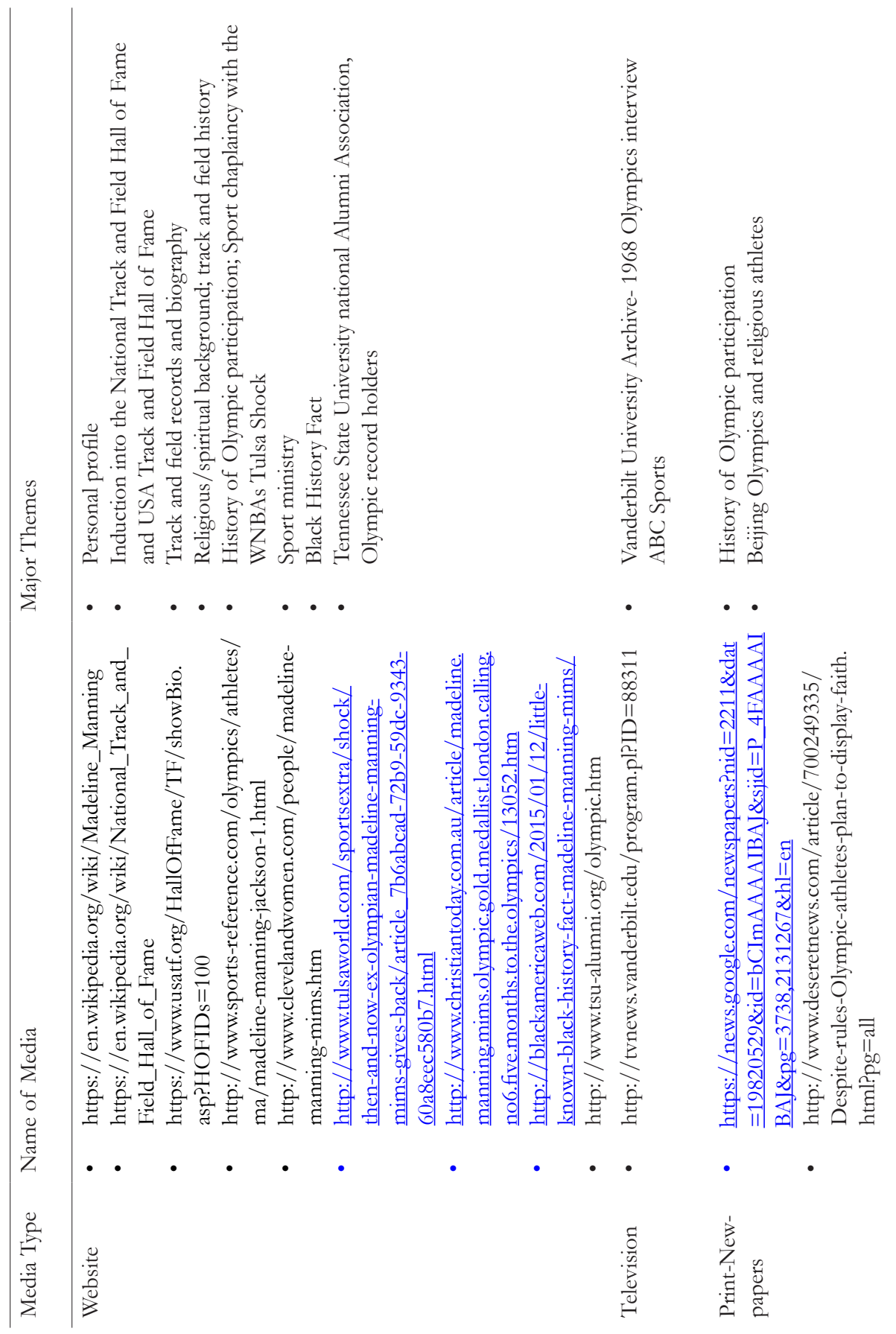


Sport Science Review, vol. XXV, No. 1-2, May 2016
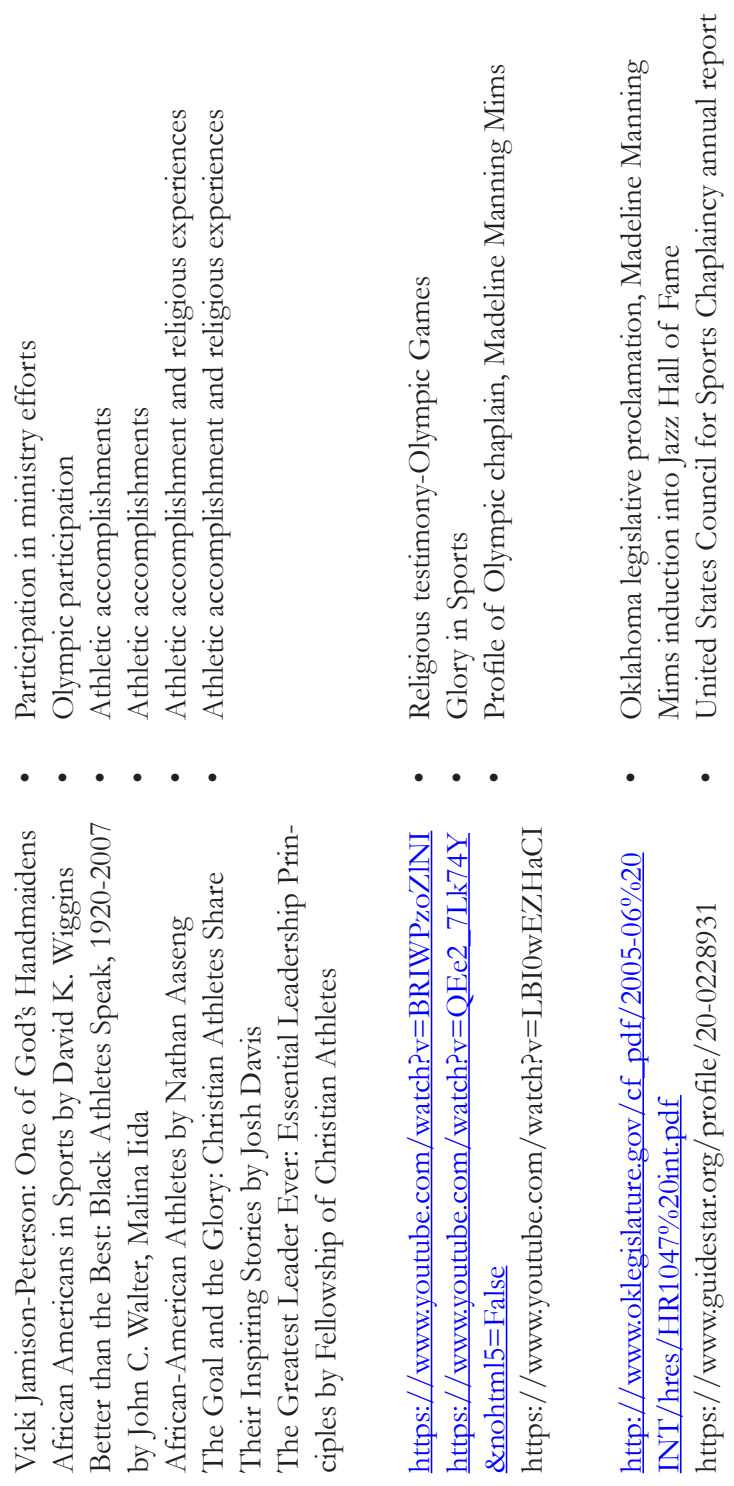

0
0
0
0
01
0
0
0

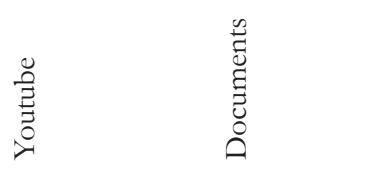

Table 1. Sources Used to Vett Madeline manning Mims 
Steven N. WALLER, PhD, DMin is an Associate Professor in the Department of Kinesiology, Recreation, and Sport Studies at the University of Tennessee- Knoxville. His research interests include: religious beliefs as a constraint to leisure/sport participation; impediments to carrier mobility for minorities and women in sport organizations; institutional evil in sport organizations; and professional identity/ credentialing of sport chaplains.

\section{Corresponding address:}

Steven N. Waller, PhD

Department of Kinesiology, Recreation, and Sport Studies

The University of Tennessee

1914 Andy Holt Ave., HPER 322

Knoxville, TN 37996-2700

865-974-1279- Office

865-974-8981- Fax

E-mail: swaller2@utk.edu

Dawn M. NORWOOD, PhD is an Assistant Professor and Program Director for the Master of Arts in Sport Management Program at Wingate University. Her research interests include strategies for overcoming constraints to swimming for African American females, the socio-cultural impact of the Negro Baseball Leagues and academic reform among collegiate student-athletes.

Fritz G. POLITE, PhD, MPA is an Associate Professor and Chair, in the Management Science Division, Harry F. Byrd Jr., School of Business at Shenandoah University (USAVA). He is a former President of the North American Society for the Sociology of Sport (NASSS) and President Elect of the Drake Group. Polite's research interests lie in the areas of social-cultural aspects of sport, social accountability and responsibility in business, and brand and vertical extension.

Lequez SPEARMAN, PhD, is an Assistant Professor in the Department of Counseling, Kinesiology and Special Education at Midwestern University in the United States. He is a member of the North American Society for the Sociology of Sport (NASSS). Spearman's research interests lie in the areas of black masculinity in sport, environmental sustainability in sport, and the decline of African Americans in baseball. 